\title{
Effect of pterygium excision on mean corneal curvature.
}

\footnotetext{
1. MBBS

Post-Graduate Trainee

Ophthalmology

Holy Family Hospital, Rawalpindi.

2. MBBS

Post-Graduate Trainee

Armed Forces Institute of

Ophthalmology, Rawalpindi.

3. Final Year MBBS Student

Rawalpindi Medical University,

Rawalpindi.

4. MBBS

House Officer Ophthalmology Holy Family Hospital, Rawalpindi.

5. Final Year MBBS Student Rawalpindi Medical University, Rawalpindi.

6. MBBS, FCPS

Professor Head Ophthalmology

Holy Family Hospital, Rawalpindi.

Correspondence Address:

Dr. Mahnoor Waqar

Rawalpindi Medical University,

Rawalpindi.

mahnoor.waqar55@gmail.com
}

Article received on:

04/04/2019

Accepted for publication:

02/06/2020

\begin{abstract}
Saira Bano', Sumaya Khan², Mahnoor Waqar ${ }^{3}$, Moniba Iqbal $^{4}$, Hamza Waqar Bhatti ${ }^{5}$, Ali Raza ${ }^{6}$
ABSRTRACT... Objective: To determine the difference in mean corneal curvatures before and after pterygium excision. Study Design: Quasi-experimental study. Setting: Department of Ophthalmology, Holy Family Hospital, Rawalpindi. Period: $1^{\text {st }}$ January 2015 to $1^{\text {st }}$ July 2015. Material \& Methods: 68 patients aged between 18 to 65 years were included in the study. Patients with history of ocular trauma, ocular surgery, glaucoma, anti-glaucoma treatment, allergy to steroids, pseudo pterygium, recurrent pterygium and presence of corneal abnormalities such as, scarring that might affect the astigmatic value were excluded. All patients underwent comprehensive ophthalmic examination by slit lamp and best corrected visual acuity and keratometric values were noted. Pterygium excision was done by a single surgeon. BCVA and keratometric readings were taken again after 2 weeks of pterygium excision. Results: Mean age was $37.60 \pm 11.11$ years. Out of these 68 patients, 44 (64.71\%) were male and 24 (35.29\%) were females. Mean pre-operative corneal curvature was $2.99 \pm 0.69 \mathrm{D}$ and post-operative corneal curvature was $1.70 \pm 0.40 \mathrm{D}$ with P-value of $<0.0001$ which is statistically significant. Conclusion: This study concluded that pterygium excision brings significant change in corneal curvature in patients of pterygium induced astigmatism.
\end{abstract}

Key words: $\quad$ Cornea, Curvature, Excision, Pterygium.

Article Citation: Bano S, Khan S, Waqar M, Iqbal M, Bhatti HW, Raza A. Effect of pterygium excision on mean corneal curvature. Professional Med J 2021; 28(4):568571. https://doi.org/10.29309/TPMJ/2021.28.04.4698

\section{INTRODUCTION}

A pterygium is a triangular fibro vascular sub epithelial ingrowth of degenerative bulbar conjunctiva tissue over the limbus onto the cornea. ${ }^{1}$ It is one of the most common conjunctival degenerative surface disorders. ${ }^{2}$ and causes problems like irritation, lacrimation, foreign body sensation but functional impairment due to reduced visual acuity, diplopia and problems in fitting contact lenses. ${ }^{3}$

Cameron has mapped the worldwide distribution of Pterygium which is highly prevalent $30^{\circ} \mathrm{N}$ and $30^{\circ} \mathrm{S}$ of the equator, hence, a relative pterygium belt straddles the equatorial region. ${ }^{4}$ According to a meta-analysis by Liu pterygium has a worldwide prevalence of $10.2 \%$. Major risk factors include exposure to sunlight and UV radiation and increased outdoor work which predisposes the eye to ocular dryness and irritants. ${ }^{5}$
Pterygium exerts a mechanical pull which leads to flattening of cornea to the leading apex resulting in significant corneal distortion and large amount of astigmatism. Various studies have measured the correlation between pterygium and curvature abnormalities by corneal topography and automated kerato-refractometry. According to these studies pterygium mostly causes 'with the rule' astigmatism and its removal causes reversion of corneal curvatures towards normal and hence improvement in visual acuity. ${ }^{6}$ According to one study the preoperative astigmatism decreased from $2.58 \pm 2.33 \mathrm{D}$ to $1.30 \pm 1.24 \mathrm{D}$ two weeks postoperatively pterygium excision $(P<0.001){ }^{7}$

This study was conducted to signify the importance of early excision of pterygium causing normalization of corneal curvatures resulting in symptomatic relief as well as early visual improvement. 


\section{MATERIAL \& METHODS}

This quasi experimental study was conducted at the Department of Ophthalmology, Holy Family Hospital, Rawalpindi, from 1st January 2015 to 1st July 2015 which included 68 diagnosed cases of pterygium by non-probability consecutive sampling technique. Study population comprised patients with primary ocular pterygium and all of them had nasal pterygium. Pterygium was diagnosed as triangularfibrovascular subepithelial growth of bulbar conjunctival tissue over at least $1 \mathrm{~mm}$ of cornea. On slit lamp examination with slit beam focused on the nasal limbus, pterygium was graded according to the extent of corneal involvement and were graded as; Grade I (less than $2 \mathrm{~mm}$ encroaching on the cornea), Grade II (2 to $4 \mathrm{~mm}$ ) and Grade III (more than $4 \mathrm{~mm}$ in the visual axis).

Patients between age group 18 to 65 years, of both genders, with complaints of decrease in visual acuity (less than 6/18), foreign body sensation and hyperemia were included. Patients with history of ocular trauma, pseudo pterygium, recurrent pterygium, ocular surgery, glaucoma, antiglaucoma treatment and corneal abnormalities such as, scarring that might affect the astigmatic value were excluded from the study. After approval of the study from the ethical committee and informed consent from Patients for surgery and their inclusion in the study preoperatively, data was collected using on self-designed proforma. The preoperative data of best corrected visual acuity (BCVA) and keratometric values were noted. The BCVA values were obtained using Snellen chart. Keratometric values were obtained via automated keratorefractometer (Canon RK F1 Japan). Keratometry was performed one day prior to surgery.

A difference of more than 1 diopter in vertical and horizontal corneal curvatures was labelled as astigmatism. Pterygium excision in all cases was done by consultant ophthalmologist. Lidocaine $\mathrm{HCL} 40 \mathrm{mg} / 2 \mathrm{ml}+$ epinephrine $0.025 \mathrm{mg} / \mathrm{ml}$ were injected into the body of the pterygium. Following removal of the body by Westcott's scissors, the head was bluntly lifted off the cornea. The abnormal scar tissue was scraped off from the cornea by using no.15 blade. Moderate amount of Tenon's capsule was carefully dissected out. Cautery was used to the scleral bed. Conjunctival autograft was harvested from the supero-temporal bulbar conjunctiva and graft was sutured over the exposed scleral bed with 6.0 vicrylsuture. Eye pad was applied for 24 hours.

After surgery every patient was given dexamethasone phosphate $0.1 \%$ eye drops four times a day and it was then tapered off in 2 weeks. BCVA and keratometric readings were taken again after 2 weeks of operation and recorded in the pro forma. Mean change in corneal curvature was measured horizontally and vertically by automated keratorefractometer. Average of the three reliable readings was recorded for every patient.

Data was analyzed by using SPSS version 23.0. Frequency and percentages for gender and grade of pterygium were determined. Mean and standard deviation were calculated for numerical data like age and corneal curvatures (preoperatively and postoperatively). Change in corneal curvature preoperatively and postoperatively was subjected to statistical significance. This difference was calculated using paired sample t-test. $P \leq 0.05$ was considered statistically significant

\section{RESULTS}

The study included 68 patients with mean age of $37.60 \pm 11.11$ years. Majority of the patients i.e. $33(48.53 \%)$ were between 18 to 35 years of age as. Out of these 68 patients, $44(64.71 \%)$ were male and 24 (35.29\%) were females with male to female ratio of 1.9:1. Majority of patients i.e. 29 (42.65\%), presented with grade I pterygium. Distribution of Patients according to age, gender, grade of pterygium and occupation is given in Table-l.

Mean pre-operative corneal curvature was 2.99 $\pm 0.69 \mathrm{D}$ and post-operative corneal curvature was $1.70 \pm 0.40 \mathrm{D}$. The mean difference was statistically significant. $(p<0.001)$ The difference between pre-operative and post-operative corneal curvature was significant in different grades of pterygium $(p<0.001)$. In grade I pterygium pre- 
operative astigmatism was $3.16 \pm 0.62 \mathrm{D}$ which reduced to $1.67 \pm 0.41 \mathrm{D}$ post-operatively. In grade II pre-operative astigmatism was $2.87 \pm 0.69 \mathrm{D}$ and post-operatively reduced to $1.73 \pm 0.42 \mathrm{D}$ while in grade III pterygium pre-operative astigmatism reduced from $2.85 \pm 0.77 \mathrm{D}$ to $1.72 \pm 0.38 \mathrm{D}$ as shown in Table-Il.

\begin{tabular}{|c|c|c|c|}
\hline \multicolumn{2}{|c|}{ Groups } & \multicolumn{2}{|c|}{$\mathrm{N}=68(100 \%)$} \\
\hline \multicolumn{4}{|l|}{ AGE } \\
\hline \multicolumn{2}{|l|}{$18-35$} & \multicolumn{2}{|c|}{$33(48.53 \%)$} \\
\hline \multicolumn{2}{|l|}{$36-50$} & \multicolumn{2}{|c|}{25 (36.76\%) } \\
\hline \multicolumn{2}{|l|}{$51-65$} & \multicolumn{2}{|c|}{$10(14.71 \%)$} \\
\hline \multicolumn{4}{|l|}{ GENDER } \\
\hline \multicolumn{2}{|l|}{ Female } & \multicolumn{2}{|c|}{$24(35.29 \%)$} \\
\hline \multicolumn{2}{|l|}{ Male } & \multicolumn{2}{|c|}{$44(64.71 \%)$} \\
\hline \multicolumn{4}{|c|}{ GRADE OF PTERYGIUM } \\
\hline \multicolumn{2}{|l|}{ Grade 1} & \multicolumn{2}{|c|}{$29(42.65 \%)$} \\
\hline \multicolumn{2}{|l|}{ Grade 2} & \multicolumn{2}{|c|}{$24(35.29 \%)$} \\
\hline \multicolumn{2}{|l|}{ Grade 3} & \multicolumn{2}{|c|}{15 (22.06\%) } \\
\hline \multicolumn{4}{|c|}{ OCCUPATION } \\
\hline \multicolumn{2}{|l|}{ Indoor } & \multicolumn{2}{|c|}{27 (39.71\%) } \\
\hline \multicolumn{2}{|l|}{ Outdoor } & \multicolumn{2}{|c|}{41 (60.29\%) } \\
\hline \multicolumn{4}{|c|}{$\begin{array}{l}\text { Table-I. Distribution of patients according to age, } \\
\text { gender, grade of pterygium and occupation. }\end{array}$} \\
\hline Groups & $\begin{array}{c}\text { Pre- } \\
\text { Operative } \\
\text { Corneal } \\
\text { Curvature } \\
\text { (Diopters) } \\
\text { (Mean } \pm \text { SD) }\end{array}$ & $\begin{array}{c}\text { Post- } \\
\text { Operative } \\
\text { Corneal } \\
\text { Curvature } \\
\text { (Diopters) } \\
\text { (Mean } \pm \text { SD) }\end{array}$ & P-Value* \\
\hline \multicolumn{4}{|c|}{ Grade of Pterygium } \\
\hline Grade 1 & $3.16 \pm 0.62$ & $1.67 \pm 0.41$ & $<0.001$ \\
\hline Grade 2 & $2.87 \pm 0.69$ & $1.73 \pm 0.42$ & $<0.001$ \\
\hline Grade 3 & $2.85 \pm 0.77$ & $1.72 \pm 0.38$ & $<0.001$ \\
\hline
\end{tabular}

Table-II. Mean differences of pre and post-operative corneal curvature distribution according to age groups, gender, grade of pterygium and occupation ${ }^{*} p \leq 0.05$ was considered significant

\section{DISCUSSION}

Pterygium causes flattening of the cornea leading to astigmatism. The flattening causes with-therule astigmatism due to flattening of the horizontal meridian which can be rectified by pterygium excision. ${ }^{8}$
In our study majority of patients with pterygium belong to a younger age bracket from 18-35 years. However, this is in contrast to other studies which have shown increased pterygium prevalence in older age groups..$^{9,10}$

A study in Pakistan and another multiethnic population study in Asians which included Chinese, Malay and Indians have shown that males and people who work outdoor are more prone to develop pterygium which is consistent with our study. ${ }^{6,11}$ This could be due to the fact that most of patients visiting our hospital belong to lower socioeconomic strata who have more outdoor work making them prone to sunlight and U.V radiations exposure which are risk factors in development of pterygium.

Surgical excision is the primary treatment for pterygium. A study by Mohite et al. showed reduction in pterygium induced astigmatism from $3.046 \pm 1.20 \mathrm{D}$ to $1.486 \pm 0.63 \mathrm{D}(\mathrm{P}<0.001)$ after surgical excision. ${ }^{12}$ Another study showed a decrease in mean pre-operative astigmatism from $3.47 \pm 1.74 \mathrm{D}$ to $1.10 \pm 0.78 \mathrm{D}(\mathrm{P}<0.0001)$ postoperatively at 3 months. ${ }^{13}$ This results are consistent with our study which showed preoperative astigmatism from $2.99 \pm 0.69 \mathrm{D}$ to $1.7 \pm 0.4 \mathrm{D}$ post-operatively. So, we recommend that there should be early excision of pterygium for normalization of corneal curvatures resulting in symptomatic relief and early visual improvement.

However, our study did not attempt to consider all the ocular parameters such as vascularity and width of pterygium, which definitely affect the value of induced astigmatism. Thus, further studies are required to establish the effect of various factors on mean corneal curvature and to document the long term results (up till one year or more) of pterygium excision on astigmatism.

\section{CONCLUSION}

Our study concluded that there is significant decrease in pterygium induced astigmatism in patients undergoing pterygium excision.

Copyright $@ 02$ June, 2020. 


\section{REFERENCES}

1. Kanski, J. and Bowling, B. (2012). Clinical ophthalmology. Oxford: Saunders.

2. Mahar PS, Manzar N. Pterygium recurrence related to its size and corneal involvement. J Col Physicians Surg Pak. 2013 Feb 1; 23(2):120-3.

3. Hussain Z, Rehman HU, Bilal M. Comparison of preoperative injection vs. Intraoperative application of mitomycin $\mathrm{C}$ in recurrent pterygium. Ophthalmology Update. 2013 Jan; 11(1):21.

4. Cameron ME. Pterygium throughout the world. Springfield, Charles C. Thomas Publisher; 1965.

5. Liu L, Wu J, Geng J, Yuan Z, Huang D. Geographical prevalence and risk factors for pterygium: A systematic review and meta-analysis. BMJ open. 2013 Nov 1; 3(11):e003787.

6. Khan FA, Khan Niazi SP, Khan DA. The impact of pterygium excision on corneal astigmatism. J Coll Physicians Surg Pak. 2014 Jun 1; 24(6):404-7.

7. Ozdemir M, Cinal A. Early and late effects of pterygium surgery on corneal topography. Invest Ophthalmol Vis Sci. 2005 Nov 1; 36(6):451-6.
8. Shelke E, Kawalkar U, Wankar R, Nandedkar V, Khaire $B$, Gosavi V. Effect of pterygium excision on pterygium induced astigmatism and visual acuity. Int $\mathrm{J}$ Adv Health Sci. 2014; 40(9):24-4.

9. Zhong H, Cha X, Wei T, Lin X, Li X, Li J, et. al. Prevalence of and risk factors for pterygium in rural adult chinese populations of the Bai nationality in Dali: The Yunnan Minority Eye Study. Invest Ophthalmol Vis Sci 2012 Sep 1; 53(10):6617-21.

10. Lim CY, Kim SH, Chuck RS, Lee JK, Park CY. Risk factors for pterygium in Korea: The Korean national health and nutrition examination survey V, 20102012. Medicine. 2015 Aug; 94(32).

11. Ang $M$, Li X, Wong $W$, Zheng $Y$, Chua $D$, Rahman $A$, et. al. Prevalence of and racial differences in pterygium: A multiethnic population study in Asians. Ophthalmology. 2012 Aug 1; 119(8):1509-15.

12. Mohite US, Dole NB, Jadhav SS. Effectiveness of pterygium surgery on corneal astigmatism. Med Pulse Int J Ophthalmol. 2017; 3:12-17.

13. Garg P, Sahai A, Shamshad MA, Tyagi L, Singhal Y, Gupta S. A comparative study of preoperative and postoperative changes in corneal astigmatism after pterygium excision by different techniques. Indian $\mathrm{J}$ Ophthalmo. 2019 Jul; 67(7):1036.

\begin{tabular}{|c|c|c|c|}
\hline \multicolumn{4}{|c|}{ AUTHORSHIP AND CONTRIBUTION DECLARATION } \\
\hline Sr. \# & Author(s) Full Name & Contribution to the paper & Author(s) Signature \\
\hline 1 & & Chief author, main concept, data & \\
\hline 2 & Sumaya Khan & $\begin{array}{l}\text { Writing of manuscript, Literature } \\
\text { search, statistical analysis. }\end{array}$ & \\
\hline 3 & Mahnoor Waqar & $\begin{array}{l}\text { Writing of manuscript, Literature } \\
\text { search, statistical analysis. }\end{array}$ & \\
\hline 4 & Moniba lqbal & Data collection analysis. & \\
\hline 5 & Hamza Waqar Bhatti & Reference, review of literature. & \\
\hline 6 & Ali Raza & Research supervision. & \\
\hline
\end{tabular}

